\title{
LEGAL CHALLENGES AFFECTING OFFSHORE TRUSTS POST 2008 FINANCIAL CRISIS
}

\author{
Mohsin Hingun*
}

\begin{abstract}
The phenomenal growth of offshore trusts valued in billions of dollars at the end of the last century as a result of its ability to attract, transfer and protect substantial sums of money from the settlor's country to overseas jurisdictions with the potential to save, reduce, avoid and evade taxes have been subjected to critical examination by tax authorities, the courts, non-governmental organisations and the media, especially in the years following the 2008 financial crisis. The objective of this paper to briefly introduce the nature and uses of offshore is trusts and to focus on some of the important challenges they face in a hostile environment. An area of evolving interest is the secrecy issue inherent in offshore trusts which has been abused as a veil for tax avoidanceltax evasion.
\end{abstract}

Keywords: offshore trusts, 2008 financial crisis, secrecy, tax avoidance

Associate Professor of Law, Ahmad Ibrahim Kulliyyah of Law, International Islamic University Malaysia. Email: mohsin@iium.edu.my. 


\title{
CABARAN UNDANG-UNDANG YANG MELIBATKAN AMANAH LUAR PESISIR PASCA KRISIS KEWANGAN 2008
}

\begin{abstract}
ABSTRAK
Pertumbuhan luar biasa amanah luar pesisir yang bernilai berbilion-bilion dolar pada penghujung abad yang lalu adalah hasil daripada keupayaannya dalam menarik, memindahkan dan melindungi sejumlah besar wang dari negara settlor kenegara-negara luar yang berpotensi untuk menjimatkan, mengurangkan, mengelakkan dan melarikan cukai yang tertakluk kepada pemeriksaan ketat oleh pihak berkuasa cukai, mahkamah, pertubuhan bukan kerajaan dan juga pihak media khususnya dalam tahun-tahun selepas krisis kewangan 2008. Objektif kertas kerja ini adalah bagi memberi pengenalan secara ringkas kepada ciri-ciri dan kegunaan amanah luar pesisir dengan memberi tumpuan kepada beberapa cabaran penting yang mereka hadapi di persekitaran bertentangan. Satu persoalan yang semakin menarik minat adalah isu kerahsiaan berkenaan amanah luar pesisir yang telah disalahgunakan untuk menyembunyikan kegiatan pengelakan/pelarian cukai.
\end{abstract}

Kata kunci: amanah luar pesisir, krisis kewangan 2008, kerahsiaan, pengelakan cukai 


\section{INTRODUCTION}

An offshore trust has become an important tool for wealth planning and preservation. Scores of financial offshore centres ${ }^{1}$ have sprung up and most of these provide facilities for the creation of offshore trusts as one of their offshore structures. Secrecy and confidentiality are hallmarks of offshore trusts, for example in some jurisdictions no registration is required and no person who has by any means access to any record, book, register, correspondence, document, material or information, relating to the business and affairs of a the trust shall give, divulge, reveal, publish or otherwise disclose to any person such record, book, register, correspondence, document, material or information without a court order. ${ }^{2}$ Coupled with this, offshore trusts provide greater protection from creditor claims and incorporate several pro-settlor provisions. ${ }^{3}$ While tax havens provided the locus for fraudulent business models such as those offered by Bernie Madoff, Allen Stanford ${ }^{4}$ and others, offshore centres offer unhealthy competition revolving around tax and regulations to attract a bigger share of world capital. ${ }^{5}$

$1 \quad$ Offshore Financial Centers IMF Background Paper' by the Monetary and Exchange Affairs Department June 23, 2000: https://www.imf. org/external/np/mae/oshore/2000/eng/back.htm..

2 See for example, Section 8A of the Malaysian Labuan Offshore Trust Act 1969 (LTA).

3 Section 8B LTA: The extensive retention of rights by settlor; S.10: Unenforceability of foreign claim or judgment; Section11D: Purpose trust not rendered void merely by uncertainty; Section16: Unlimited duration of Labuan trust made possible; Sections 12,13: Registration of Labuan trust and trust instrument discretionary; S.35: Appointment of protector for substantial control over trustees.

4 Connyersdill \& Pearman, "Positively Offshore", http://www. conyersdill.com/publicationfiles/Article_099_09_10_21_ Positively_Offshore.pdf.

5 Tax Justice Network, "Tax Wars", http://www.taxjustice.net/topics/ race-to-the-bottom/tax-wars/ 


\section{THE NATURE AND USES OF OFFSHORE TRUSTS}

In England the early emergence of the use, a device which enabled the transmission of property developed into trust by the thirteenth century, under which the legal title vested in the trustee while the beneficiary could in equity enforce the terms of the trust enabling him to derive the benefit he was intended to be given by the settlor. Originally recognised and enforceable by the Court of Chancery, Underhill describes a trust as follows:

A trust is an equitable obligation binding a person (who is called a trustee) to deal with property over which he has control (which is called the trust property), for the benefit of persons (who are called beneficiaries or c'estui que trust), of whom he may himself be one, and any one of whom may enforce the obligation. Any act or neglect on the part of a trustee which is not authorised or excused by the terms of the trust instrument, or by law, is called a breach of trust. ${ }^{6}$

The main features of a trust are:

- a 'settlor' the owner of property creates the trust and the terms of the trust with the trustee for the benefit of the beneficiaries

- $\quad$ it is a legal relationship, under which a trustee manages the assets for a 'beneficiary';

- the trustee owes fiduciary duties not to the settlor but to third party beneficiaries.

- $\quad$ it is the beneficiaries as equitable owners who have locus standi to enforce the terms of the trust.

In a typical trust the creator of the trust (the settlor) transfers property to trustees who manage the property for the benefit of beneficiaries. Trustees as legal owners are given powers of managing the property and beneficiaries as equitable owners can enforce the

$6 \quad$ Underhill, Law of Trust and Trustees, 17 $7^{\text {th }}$ Ed., (Lexis Nexis Butterworth, 2010). 
trust. It is a very flexible and versatile instrument, and its development over the centuries, has been in the words of the modern jurist $\mathrm{F} \mathrm{W}$ Maitland, 'the greatest and most distinctive achievement performed by Englishmen in the field of jurisprudence. ${ }^{7}$

Today the flexibility of trusts has manifested in various types, for example they can be fixed, discretionary, secret, protective, charitable or non-charitable and under certain circumstances, they can be implied by the law as constructive or resulting trusts.

Although in medieval times trusts were used to avoid certain forms of feudal taxation and to manage property for illiterate beneficiaries (women and children of crusaders), today they are widely used as a tool for planning and managing the family wealth and have assumed increasingly greater importance in the field of investment such as unit trusts, pension funds and as a favourite vehicle for tax planning.

Over the past decades it is the offshore trust that has been able to attract enormous sums of money and it can with ease be created in over 150 offshore jurisdictions all over the world. An offshore trust is similar in nature to an onshore trust except that it is formed under the laws and jurisdiction of another country. As creator of the trust, normally the settlor is non-resident and immovable property situated in the chosen offshore jurisdiction cannot be included in the subject matter of the trust. ${ }^{8}$

A typical description of an offshore trust is provided by S.3 of the Labuan Trust Act 1996 (LTA) as follows:

"A trust exists where a person holds or has vested in him or is deemed to hold or have vested in him property of which he is not the owner in his own right and is under an obligation as a trustee to deal with that property-

(a) for the benefit of any beneficiary, whether or not ascertained or in existence;

(b) for any purpose which is not for the benefit of the trustee; or

$7 \quad$ F W Maitland, The Collected Papers of Frederick William Maitland, Vol. 3, (Cambridge University Press, 1911).

8 In Labuan, Malaysia, the settlor can even be a resident and Malaysian property may be included in the offshore trust subject to approval: LTA Section 7(1), (2). 
(c) for both such benefit and purpose mentioned in paragraphs (a) and (b)."

Offshore trusts are very popular vehicles available in many offshore jurisdictions including tax havens and they can be used to manage assets for a number of reasons, some of which are:

$\begin{array}{ll}\text { - } & \text { Asset protection } \\ \text { - } & \text { Tax planning } \\ \text { - } & \text { Avoiding forced heirship rules } \\ \text { - } & \text { Confidentiality and anonymity } \\ \text { - } & \text { Protection from creditors } \\ \text { - } & \text { Avoiding Inheritance taxes }\end{array}$

Two of the more important reasons are protection of assets through overseas asset protection trusts (OAPTs) and tax avoidance schemes through which tax payable can be reduced or eliminated. It must also be borne in mind that the potential for abuse of offshore trusts is well documented. However capitalising on the anonymity and confidentiality features, illegally obtained gains can be deposited in offshore trusts for the purpose of money laundering or concealing the gains from claimants.

Although initially these trusts were available to the very rich, rapid development in travel and communications coupled with unregulated advertisements extolling the virtues of offshore finance planning meant that by 1980, scores of offshore jurisdictions were competing with each other to offer this service. To attract offshore trust business through the creation of a favourable legal environment has resulted in very settlor-friendly legal provisions which have been framed without the wider ethical considerations as to render offshore trusts as attractive as possible to offshore clients.

\section{The Structure of The Offshore Trust}

Traditionally once a trust has been created, legal title to the subject matter vests in the trustees who hold and manage the trust property for the benefit of the beneficiaries. The parties to a completely constituted 
trust are bound by the trust and the settlor cannot alter its terms. ${ }^{9}$ The typical offshore trust will contain a number of protective devices that will enable the settlor to exercise substantial control over the trust property and protect against adverse changes in circumstances. For example a trust protector clause allows the settlor at his discretion to appoint a protector as an advisor to the trustee and who is charged with making sure that the trustee carries out the settlor's wishes. In some cases, the consent of the protector may be necessary for the trustee to perform certain acts. In addition, the protector may be empowered to remove the trustee, change the beneficiaries or even change the situs of the trust. Section 35 of LTA 1996 provides that the terms of a trust may expressly require the appointment of a protector who shall be consulted upon by the trustee in the exercise of all or certain specified powers as may be provided in the terms of the trust. It also allows either the settlor or a beneficiary to be the protector with extensive powers:

a. to remove a trustee and to appoint a new or additional trustee, but if the protector removes a trust company as a trustee, the protector shall appoint another trust company as a new trustee in its place

b. to determine the law of which jurisdiction shall be the proper law of the trust, in the event it is not provided in the trust deed or by the settlor;

c. to change the place of administration of the trust; and

d. to withhold consent from specified actions of the trustees either conditionally or unconditionally.

\section{Asset Protection}

In an asset protection trust (APT) ownership of property is transferred by the "settlor" (person creating the trust), to the "trustees"(person managing the trust), for the benefit of beneficiaries or a charitable purpose. The trust is created by executing a legal document known as the "trust deed" or "trust instrument". Sometimes the settlor also appoints a protector who will have the duty of controlling the trustees. The settlor can even appoint himself as one of the protectors. It is a trust set up with an objective of adding a layer of protection to one's assets.

$9 \quad$ Paul v Paul (1882 20 Ch 742); Re Bowden (1936 Ch. 71). 
It is normally an offshore trust. Over the years, wealthy individuals have had recourse to offshore trusts in scores of locations including Jersey Island, Cook Islands, Bahamas, Cayman Island, Mauritius and Labuan in Malaysia. It is true that, to establish and maintain an asset protection trust, it will be costly, but nevertheless it is a way to ensure that the trust assets will be out of the reach of most creditors and other financial predators. Just like other types of trust, the settlor, will transfer the assets into the trust and there will be trustees who will administer the assets.

The APT is founded on the principle that the transfer of the legal title of the subject matter in the offshore trustees removes its ownership from the settlor. The subject matter is kept out of creditors' reach removing the incentive to litigate. Wealthy people including successful professionals, film stars and others have been using this method of asset protection. The APT provides lots of benefits to the settlor. It protects his wealth and assets transferred to the trust giving him the right to enjoy his wealth but keeping it out of creditors' claims. It affords him personal security and safety. It also provides total privacy, especially in jurisdictions where there is no obligation to get the trust registered. He can also be protected from forced heirship rule if he wants to bypass such inheritance laws of his country.

\section{Protection from Creditors}

Invalidation of trusts to defeat the rights of creditors has a long history. English law forbids an individual to transfer his property into a trust to shield it from his creditors. ${ }^{10}$ The Statute of Elizabeth (1571) equally prohibits conveyances made with the "intent to delay, hinder or defraud creditors or others of their just and lawful actions." The spirit of this old statute has been maintained in several modern common law jurisdictions. ${ }^{11}$

$10 \quad$ Re Butterworth (1882) LR 19 Ch D 588, per Jessel MR: The principle of Mackay v. Douglas (1872) LR 14 Eq 106, and that line of cases, is this, that a man is not entitled to go into a hazardous business, and immediately before doing so settle all his property voluntarily, the object being this: "If I succeed in business I make a fortune for myself. If I fail, I leave my creditors unpaid. They will bear the loss."

11 For example see, Section 172 Law of Property Act 1925 (UK); Section 60(1) Law Act 1952(New Zealand Property). 
Notwithstanding this prohibition, many settlors protect their assets from their creditors by creating trusts for the benefit of their families with the intention of preventing their creditors' access to their assets. Several jurisdictions have enacted laws to prevent fraudulent transfers which prohibit a debtor from transferring assets in order to hinder, delay or defraud creditors. A court will set aside a fraudulent transfer enabling the creditor to recover the debt from the transferred property. ${ }^{12}$

However, most offshore jurisdictions and financial centres have repealed the Statute of Elizabeth and replaced it with weaker fraudulent conveyance standards, making these centres more attractive for offshore asset protection trusts. The provisions of most offshore legislations potentially weaken the ability of the creditors to reach assets under fraudulent conveyance law. For example, an offshore trust created in Malaysia requires proof beyond reasonable doubt, the onus of which is on the claiming creditor, to prove that the Labuan trust was so created by or on behalf of the settlor with the principal intent to defraud the creditor and at the time such creation took place, rendered the settlor, insolvent or without property by which that creditor's claim, if successful, could have been satisfied. ${ }^{13}$ In addition to the high burden of proof required on the part of the creditor, a shorter limitation period is imposed. In a Labuan trust the creditor is given only a two year period to bring his claim after which it is statute-barred, ${ }^{14}$ and a settlor shall not have imputed to him an intent to defraud a creditor solely by reason that the settlor has created or registered a Labuan trust or has disposed of property to such trust within two years from the date of that creditor's cause of action accruing; or that the settlor is a beneficiary. ${ }^{15}$

However if the transaction between the creditor and debtor occurred after the funds were transferred into the trust, most offshore jurisdictions will not allow, as a matter of law, an action to set it aside as fraudulent. ${ }^{16}$

$12 \quad$ See, Regal Castings v Lightbody and Ors [2009] 2 NZLR 433(New Zealand) in which the transfer of the family home to the family trust was set aside as it had been made with intent to defraud creditors. Section 11 (1) Labuan Trusts Act 1996. Similar provisions can be found in Cook Islands and several other offshore centres.

$14 \quad$ Section 11 (2) Labuan Trusts Act 1996.

$15 \quad$ Section 11 (5) Labuan Trusts Act 1996.

16 Patterson v Shumate, 504 U. S. 753 (1992). 


\section{Forced Heirship Rule and Offshore Trust}

The forced heirship rule applies to limit the discretion of the testator to distribute assets under a will. It can be found in civil law countries and countries where the applicable inheritance law is Islamic law. This rule provides for shares fixed by law to a family member in the estate of a decedent despite the fact the decedent desired to exclude that family member under his dispositive testamentary documents. Lawyers, who are in favour of the forced heirship rule, put forward the view that this is a perfectly proper practice and testators should be forced to vary their will if they are leaving destitute dependants. The countries recognizing forced heirship rule, do so with the aim that testators make adequate provision for their dependants. Consequently, an individual's parents, spouse and children will usually be entitled, by law, to a fixed share of his estate on his death. One of the easier ways of circumventing this rule is through an offshore trust. Once the offshore trust is created the office of trusteeship will not expire. Trustees can be replaced if the need arises and in extreme cases the Court will assist in the appointment as Equity will not allow a trust to fail for want of a trustee.

\section{CHALLENGES}

\section{Secrecy and Confidentiality}

After the financial crisis of 2008, several developed countries in Europe and the USA found themselves cash-strapped and launched a campaign to ensure that their citizens who invest offshore contribute their fair share of money to the Inland Revenue. In 2009 the USA took United Bank of Switzerland (UBS) to task for refusing to disclose financial information on their American clients with offshore accounts. To avoid criminal prosecution UBS agreed to pay $\$ 780$ million in fines, penalties and restitution to the U.S. government and to disclose the names of those suspected of avoiding/evading U.S. taxes. The bank ought to have withheld $\$ 400$ million from the clients as tax payable to the US Government which it had failed to do. In 2012, one of Switzerland's oldest banks, Wagelin founded in 1741 was charged with conspiracy to defraud the USA of more than \$1 billion by assisting wealthy Americans to evade taxes through secret 
accounts. In January 2013 it pleaded guilty and agreed to pay $\$ 57.8$ million to the United States in restitution and fines and has plans to close down after the case is fully settled.

Although offshore centres and the vehicles they provide are shrouded in secrecy, they have not been immune from leaks. Whistle blowing ${ }^{17}$ on offshore trusts and bank accounts has brought to public knowledge what was supposed to be very confidential and anonymous. Following leads from disclosures certain countries are taking action to recover unpaid taxes and fraudulent transfers. ${ }^{18}$

Following these cases and more than a dozen other Swiss banks under investigation, Switzerland a well-known bastion of secrecy and a tax haven reached a historic accord on August 29, 2013 with the United States to allow some Swiss banks to disclose information and to participate in a settlement program with the US Department of Justice. This would enable these banks to avoid criminal prosecution in connection with Swiss accounts maintained by US taxpayers. An essential element of the program requires these banks to provide information that will assist the United States to trace money to Swiss and other banks located internationally. ${ }^{19}$

$17 \quad$ For an account 'secret' information released by the prominent whistle blower, Julian Assange and his collaborators in modern history, see the website Wikileak: https:/wikileaks.org/; for collaboration of ex Swiss banker, Rudolf Elmer who handed Assange two CDs reputedly containing details of up to 2,000 wealthy individuals and corporations, including 40 politicians and various celebrities described as 'high net worth' individuals from Britain, America, Germany, Austria, Asia and 'all over', he wanted to expose mass tax evasion, see Daily Mail(UK) 18 Jan 2011: http://www.dailymail. co.uk/news/article-1347950/WikiLeaks-reveal-Swiss-bank-accountdetails-tax-evader-celebrities-politicians.html.

18 For example India made a formal request to Switzerland to provide it with a list of Indian residents with bank accounts in Swiss banks.

19 For an account of Credit Suisse AG's guilty plea and \$2.6 billion fine payment in a high-profile case brought by the Justice Department for helping U.S. taxpayers conceal assets, see:http://www.cbc.ca/news/business/credit-suissefined-2-6b-for-ass is ting-u-s-tax-evasion-1.2647651. The criminal resolution follows a Senate subcommittee investigation after a finding of more than 22,000 U.S. clients holding Swiss bank accounts, totalling $\$ 10$ billion to $\$ 12$ billion. 
A good example of the synergy provided by whistle blowing, inter-governmental cooperation and a proactive judiciary is the current developing event (October 4014) in India where high profile personalities who have foreign Swiss bank accounts have been exposed and will very likely face massive fines or prosecution. Details of 627 Indians holding accounts in HSBC Bank, Geneva, were handed over by the Attorney General to the Supreme Court on demand, which directed its special investigating team (SIT) to examine them and take appropriate action. The information was stolen from HSBC, handed over to France and Germany which in turn agreed to pass it on to the Indian government. ${ }^{20}$ The Supreme Court scheduled the next hearing for December 3, 2014 and has directed the SIT to submit a status report by November 30 after ascertaining the holders of black money in foreign accounts.

\title{
Tax Information Exchange Agreements (TIEAs)
}

The initiative against harmful tax practices launched by the OECD in 1998 received positive support by a number of countries including well known jurisdictions offering offshore financial services. The purpose is stated in Article 1 of each TIEA:

\begin{abstract}
Exchange of information that is foreseeably relevant to the administration and enforcement of the respective laws of the Contracting Parties concerning taxes covered by this Agreement, including information that is foreseeably relevant to the determination, assessment and collection of such taxes, the recovery and enforcement of tax claims, or the investigation or prosecution of criminal tax matters. ${ }^{21}$
\end{abstract}

TIEAs are bilateral agreements which facilitate the exchange of tax information. It allows upon request the exchange of tax information between signatories to the agreement.

\footnotetext{
20 http://www.hindustantimes.com/business-news/centre-to--discloseblack-money-full-list-to-sc-today-/article1-1279996.aspx. 
Scores of jurisdictions ${ }^{22}$ have entered into bilateral agreements and some TIEAs have even been signed by individual countries. ${ }^{23}$

\title{
The Foreign Account Tax Compliance Act, USA (FATCA)
}

The objective of FATCA, enacted in 2009 is to combat tax evasion by US citizens holding investments in offshore accounts. It requires U.S. taxpayers holding foreign financial assets with an aggregate value exceeding $\$ 50,000$ to report certain information about those assets on a new prescribed form that must be attached to his annual tax return. Reporting applies for assets held in taxable years beginning after March 18, 2010. Failure to report foreign financial assets will result in a penalty of $\$ 10,000$ to $\$ 50,000$ for continued failure. Additionally there is a penalty on the unpaid tax. It also requires foreign financial institutions ("FFIs") to report directly to the Inland Revenue Service certain information about financial accounts held by U.S. taxpayers, or by foreign entities in which U.S. taxpayers hold a substantial ownership interest. FATCA reporting due to commence in 2015 has become a potent armoury in the USA arsenal of anti-tax avoidance devices:

\begin{abstract}
"FATCA's reach is truly breathtaking. Every single non-U.S. entity in the world has a FATCA classification. This is as true for a shell company with no assets or activity as it is for the biggest multinational. It is as true for the most informal two-person partnership in the most far-flung country on the planet as it is for the most massive offshore fund. And it is also true for every non-U.S. trust, even though trusts aren't really entities." ${ }^{24}$
\end{abstract}

The aggressive outlook of the US to combat tax avoidance and the development of devices such as TIEAs and FATCA no doubt pose a serious challenge to offshore trusts which are traditionally shrouded in veils of secrecy:

22 http://www.oecd.org/tax/transparency/exchangeoftaxinformation agreements.htm.

23 http://www.oecd.org/ctp/harmful/43775845.pdf.

24 Peter A. Cotorceanu, "FATCA and Offshore Trusts: A Second Bite Of the Elephant", Taxanalysts, Oct 23, 2013. 
"It isn't a secret that one of Fatca's central aims is to "out" offshore trusts that have concealed assets from the IRS and others. As a result, says Steven Cantor, a lawyer at Cantor \& Webb in Miami who often advises multinational families, "Trusts are the area of most complexity and uncertainty" in Fatca for individuals. He and others say the law even could require reporting of a foreign trust that a beneficiary doesn't know about or receive money from-if that person has a green card or is a U.S. citizen." ${ }^{25}$

\section{Intergovernmental Agreements (IGAs) UK}

Following the USA FATCA model the UK is aiming at a similar information exchange on its UK resident taxpayers, initially focusing on financial services businesses in its Crown Dependencies and Overseas Territories (CDOTs) - Jersey, Guernsey, the Isle of Man, Gibraltar, the British Virgin Islands, the Cayman Islands, Bermuda, Montserrat, the Turks and Caicos Islands and Anguilla - and currently extended to a total of 42 countries which include many of its former colonies and famous offshore centres by signing IGAs. ${ }^{26}$ As from 2016 this mechanism will ensure the UK's access to information and data on assets held by British taxpayers offshore. Among others, service providers of trusts who deal with offshore trusts and companies will fall under Financial Institutions (FIs) and will need to consider their reporting obligations in respect of the financial accounts they maintain. ${ }^{27}$

\section{Emergence of Global Organisations Aggressive to Offshore Financial Centres}

Recent unparalleled advanced development in information technology spawning the democratization and free exchange of information worldwide, has enabled interest groups to create organisations to

25 Laura Saunders, "Offshore Accounts: No Place to Hide?", WSJ, Sept 20, 2013: http://online.wsj.com/news/articles/ SB10001424127887324807704579085511331606786.

$26 \mathrm{https} / /$ www.gov.uk/government/collections/automatic-exchange-ofinformation-agreements.

27 http://www.hmrc.gov.uk/fatca/index.htm. 
campaign for and advance their causes. The International Consortium of Investigative Journalism ${ }^{28}$ (ICIJ) and Tax Justice Network (TJN) are examples of successful organisations which have campaigned aggressively and effectively against the activities of offshore finance. The ICIJ is a global network of 185 investigative journalists in more than 65 countries who collaborate on in-depth investigative stories. It works with leading news organisations internationally in a collaborative effort to be 'the eyes and ears round the world' to expose 'cross-border crime, corruption, and the accountability of power.' In June 2013 it created the ICIJ Offshore Leaks Database ${ }^{29}$ which contains ownership information about companies created in 10 offshore jurisdictions including the British Virgin Islands, the Cook Islands and Singapore. It covers nearly 30 years until 2010 and provides sensitive information on offshore accounts and their owners exposing a wide range of wealthy individuals from shady businessmen to corrupt government officials and politicians who have amassed huge sums of money with the intention of money laundering or tax avoidance. The current tax avoidance crackdown and investigation of wealthy corrupt officials in many countries, particularly in India and China is the result of the ICIJ leaks. The reason for ICIJ doing this is 'because the political climate has changed so much over the past few months, ever since we published the second part of a multi-year investigative series that aims to strip away the secrecy associated with tax havens. ${ }^{30}$

Tax Justice Network is an independent international network launched in 2003 'dedicated to high-level research, analysis and advocacy in the field of international tax and the international aspects of financial regulation. ${ }^{31}$ It seeks to 'map, analyse and explain the role of tax and the harmful impacts of tax evasion, tax avoidance, tax competition and tax havens. ${ }^{32}$ Its particular focus is the world of offshore tax havens and it blames the offshore jurisdictions of impoverishing developing countries by providing funds from these countries a sanctuary from investigation of corruptive practices and tax avoidance.

\footnotetext{
$28 \quad$ http://www.icij.org.

29 http://offshoreleaks.icij.org/search.

30 http://www.icij.org/blog/2013/06/icij-database-cracks-open-secretworld.

31 http://www.taxjustice.net/about/who-we-are/goals/.

32 Ibid.
} 


\section{Onerous Court Decisions}

\section{Residency of Trusts}

The usual test of residency of offshore trusts is determined with reference to the residency of trustees. Since an offshore trust is located overseas, as are the trustees, the residency of the foreign trustees is determinative of the trust residency. Recently in St. Michael Trust Corp v Her Majesty The Queen ${ }^{33}$ Canadian settlors created offshore trusts in Barbados, where unlike Canada, capital gains are not subjected to tax. Two years later shares in a Canadian holding company, the subject matter of the trusts were disposed realising a gain of $\$ 478$ million. The trusts claimed the exemption from capital gains tax under the relevant treaty, which provided that only the contracting state of which the seller is a resident has the right to capital gains tax from the disposition. Assuming the trusts were resident in Barbados, there would be no tax on the realized capital gain. The Tax Court of Canada held that the corporate residence test with modifications applied to determine the residence of trusts. The Judge concluded that the central management and control test as enunciated in De Beers Consolidated Mines, Ltd. v. Howe ${ }^{34}$ was equally applicable to trusts. Since the role of the Barbados trustees was limited to administrative matters dictated by the central management and control exercised by Canadian individuals the trusts were resident in Canada. The Federal Court of Appeal upheld the decision of the lower court and the Supreme Court of Canada ${ }^{35}$ approved the reasoning of the Judge in the Tax Court:

"As with corporations, residence of a trust should be determined by the principle that a trust resides for the purposes of the Act where "its real business is carried on" (De Beers, at p. 458), which is where the central management and control of the trust actually takes place. As indicated, the Tax Court judge found as a fact that the main beneficiaries exercised the central management and control of the trusts in Canada...

\begin{tabular}{ll}
\hline 33 & [2012] 1 SCR 520. \\
34 & [1906] A.C. 455. \\
35 & 2012 SCC 14 at Para 15.
\end{tabular}


Therefore, on this test, the trusts must be found to be resident in Canada. This is not to say that the residence of a trust can never be the residence of the trustee. The residence of the trustee will also be the residence of the trust where the trustee carries out the central management and control of the trust, and these duties are performed where the trustee is resident. These, however, were not the facts in this case..."

\section{The rule in Hasting Bass - A New Direction}

In re Hastings-Bass Deceased ${ }^{36}$ established a mechanism that allowed the Court, in certain circumstances, to set aside actions taken by trustees which had unintended results, including tax consequences. It was explained by Lloyd LJ in Sieff $v$ Fox ${ }^{37}$ as follows:
"Where trustees act under a discretion given to them by the terms of the trust, but the effect of the exercise is different from that which they intended, the court will interfere with their action if it is clear that they would not have acted as they did had they not failed to take into account considerations which they ought to have taken into account, or taken into account considerations which they ought not to have taken into account."

The rule was intended to protect beneficiaries, but has also been used to exculpate trustees to undo something they have done where the effect is different from that which they had intended. For example In the Matter of Seaton Trustees Limited" ${ }^{38}$ it was applied to "turn back the clock" because trustee's misinterpretation of advice resulted in an unintended substantial inheritance tax on the beneficiary. The trustee's action caused the beneficiary in incurring an inheritance tax liability of just over $£ 1.5 \mathrm{~m}$ against an anticipated liability of approximately

\begin{tabular}{ll}
\hline 36 & {$[1975]$ Ch 25.} \\
37 & [2005] 1 WLR 3811. \\
38 & (2009) JRC 50.
\end{tabular}


$£ 100,000$. An admission was made by the trustee that its incorrect interpretation of professional advice informed the decisions it took to implement the transactions. It was held that the Hastings-Bass principle applied to the facts and the transactions were set aside.

Recently the English Court of Appeal in Pitt v. Holt ${ }^{39}$ held that the law took" a seriously wrong turn" twenty years ago in that there is in fact no such "rule" although it has been successfully invoked by trustees to undo transactions resulting in unintended tax consequences. Successful reliance on the rule required an applicant to show a breach of fiduciary duty or breach of trust on the part of the fiduciary or trustee. On appeal, the Supreme Court confirmed the judgment given by the Court of Appeal, and clarified that there is unlikely to be a breach of fiduciary duty where that fiduciary has obtained and followed professional advice. The effect of this ruling will act as a deterrence limiting its use in the English courts. In future applications are more likely to be made by the beneficiaries as trustees will require an admission of breach of duties. Although in Jersey, the offshore trust law as amended by The Trusts (Amendment No.6) (Jersey) Law 2013 provides a clear statutory framework for applications made on the basis of the rule in HastingsBass and the doctrine of mistake, a substantial number of offshore jurisdictions which either follow English law or where English cases are persuasive authority will adopt the doctrine in Pitt $v$ Holt which poses new challenges to both trustees and beneficiaries.

\section{Sham Trusts: The Ghost of Rahman v Chase Bank}

Abdel Rahman v Chase Bank (CI) Trust Co Ltd ${ }^{40}$ concerned a trust in which the settlor exercised essentially full control over the trust and its assets. On several occasions, the settlor withdrew substantial funds from the trust fund without the knowledge of or, it appeared, any complaint by the trustee. Since the settlor and trustee treated the trust fund as the settlor's own property it was held that it was a sham.

The often cited dicta of Diplock LJ in Snook $v$ London and West Riding Investments Limited ${ }^{41}$ provides a classic definition of sham:

\begin{tabular}{ll}
\hline 39 & [2011] STC 809. \\
40 & {$[1991]$ JLR 103. } \\
41 & {$[1967]$ 2 QB 786 at 802.}
\end{tabular}


"if it has any meaning in law, it means acts done or documents executed by the parties to the "sham" which are intended by them to give to third parties or to the Court the appearance of creating between the parties legal rights and obligations different from the actual legal rights and obligations (if any) which the parties intend to create."

The principle was developed further by the Jersey Royal Court in Re The Esteem Settlement, Group Torras SA v Al-Sabah \& Ors ${ }^{42}$ which has subsequently been followed in the UK High Court decision of Shalson $v$ Russo. ${ }^{43}$ Following these cases, a sham trust claim requires proof of a common intention of both the settlor and the trustees that the trust assets should be held otherwise than as set out in the trust deed and they had a common intention to mislead third parties by giving a false impression of the position.

It is submitted that given offshore trusts being pro-settlor in nature and the latitude afforded to them to control the trustees through the appointment of protectors, there is risk that they can be challenged as sham. The Privy Council in TMSF v Merrill Lynch ${ }^{44}$ held that the settlor's unfettered power to revoke meant the trust could be treated as his property and could be claimed by the settlor's bankruptcy receivers for the benefit of his creditors.

\section{CONCLUSION}

In 2008 we experienced the greatest financial crisis since the Great Depression of 1929. It has caused and is still causing recession and liquidity crisis in several economies including the USA and many other developed European nations, jolting these governments including the OECD to make conscious efforts to enrich their treasury as much as possible by plugging loopholes that encourage loss of funds. The main concern has been the avoidance of taxes. This policy has

\begin{tabular}{ll}
\hline 42 & [2004] WTLR at 54. \\
43 & {$[2005] \mathrm{Ch} \mathrm{281.}$} \\
44 & {$[2011]$ UKPC 17.}
\end{tabular}


caused a reassessment of financial structures including offshore trusts, challenging their potential to accumulate huge sums of money secretly in offshore jurisdictions and their use in reducing the tax burden of settlors and beneficiaries. It is submitted that in the aftermath of the financial crisis, offshore trusts will experience increasing examination and analysis to curtail their unrivalled advantage of secrecy and confidentiality and their use in tax avoidance or evasion schemes 